\title{
Economies of private trees: impact on income distribution at Badikhel, (Lalitpur, Nepal)
}

\author{
Keshav R. Kanel ${ }^{1}$ and Anuja R. Sharma ${ }^{2}$
}

\begin{abstract}
Land ownership in South Asia is inequitable. This paper attempts to explore type of landholding by wealth class and quantifies the impact of income from private trees. It also assesses the possession of private trees by wealth class in order to determine the contribution to household income and subsequent impact on income distribution.
\end{abstract}

The research uses comprehensive tools, both conventional surveys and Participatory Rural Appraisals, particularly wealth ranking to delineate rich and poor household and is conducted on forty-two households of Badikhel Village Development Committee, Lalitpur District.

The research reveals, "income from private trees, including subsistence use, contributes from 3.8 to 5.8 percents of household income". Pakhabari (less productive, non-irrigated and often terraced upland) is an important land resource that is also in possession of poor households. Intensity of land use by wealth class is not valid while introduction of trees in land may have other dimensions (religion, culture, etc). There is no negative impact of tree growing on the income of poor group. The rich household owns more private trees than the poor household, both on absolute term and on average, however the difference is not significant in Chi square test. There is no preferential difference in trees among the rich and poor groups. The average monthly income from private trees for poor and rich group is NRs 117 and 296 respectively (US $\$ 1=N R s 75$ ). An important finding of the paper" is "income from private trees has dis-equalising effect on income distribution and subsequently increases the poor-rich gap". These findings have sobering effect on equity related issues regarding Community Forestry in Nepal. The paper strongly recommends further research on private resource endowment before harshly criticising certain practices prevailing in Community Forestry in the name of equity in Nepal.

Keywords: private trees, wealth class, household, income distribution, community forestry

$\mathbf{L}$ and ownership in South Asia is inequitable. It is widely claimed that rural agrarian societies in Nepal are rapidly transforming under emerging marketing influences. The farmers involve themselves in various off-farm, cash earning activities. Besides shifts in the pattern of cultivation and animal husbandry, trees are grown or retained in private lands. Yet these changes are not reflected in Nepal's Forest Policies. The Government is often held responsible for neglecting commercial aspect of Community Forestry (Malla 1993).

It is also argued that the continued emphasis on protection and limited utilisation of community forest for subsistence needs means that only the private tree growers currently benefit from the opportunities

provided by the market. The criticism often goes to the extent that the Forest Department acts under the influence of tich people who own more private trees.

Besides its subsistence-oriented policy, Community Forestry is also criticised for equal distribution of forest products on the ground of equity. It is argued that since the poor households possess less land and few private trees ${ }^{3}$, they invariably depend more on community forests for satisfying their needs hence the question of equity arises (Malla et al. 2000).

In this paper, we attempt to explore the type of land owned by weal th class, assess its effect on tree-holding and subsequent impact on income distribution. In general, land is categorised into two types namely:

\footnotetext{
' Deputy Director General, Community Forestry Division, Department of Forests, Nepal.

${ }^{2}$ Forest Officer, Department of Forests, Nepal.
} 
Khet and Pakbabari. The former is an irrigated wetland where rice is cultivated and mainly owned by the rich households while the latter is dry upland, also owned by the poor households. As trees are mostly retained in the latter, this paper quantifies the impact of income from private trees on its socially justifiable distribution ${ }^{4}$.

As the agrarian society transforms from closed to open economy, subsequent national development plans emphasise not on basic need fulfilment but on poverty reduction. The question: 'can income from private trees help to narrow down poor-rich gap?' becomes imperative. The present attempt is to assess the contribution of private trees on household income and the impact of this endowment for a socially justifiable distribution of income.

Hence, in this paper, we try to answer the following questions:

1. Is there any significant difference between poor and rich households regarding private treeholdings?

2. What is the impact of income from private trees on socially justifiable distribution?
For answering these questions, assessment of land ownership by wealth class and retention of trees on private lands is necessary.

\section{Method}

The paper is based on a research conducted at Kumariban Forest User Group of Badikel Village Development Committee, Lalitpur District. The group comprised of 112 households mainly of Brahmin ${ }^{5}$ and Pahari ${ }^{6}$ castes. Wealth ranking is carried out to determine the economic standings of the community by using card-sorting method. At the initial stage of card sorting, three different colours are introduced for categorising households as per the respective economic standings? ${ }^{7}$. The ratio of poor: rich household is 0.43: 0.57 respectively. A detail description of the procedure is available in Filius and Sharma $(2000)^{8}$. The income variances method, developed after Heerink $(1997)^{9}$ is used to calculate impact on income distribution (see Box-1).

A survey was administered in 42 households, stratified into poor and rich groups, during July-August 1998. The questionnaire included questions on landholdings, number and type of private trees by

\section{Box-1: Income variance method}

$\operatorname{Var}(X)=\Sigma N_{i} / N * \operatorname{Var}\left(X_{j}\right)+\Sigma N_{j} / N^{*}\left(X_{i}-X\right)^{2}$

With $\operatorname{Var}\left(X_{i}\right)=1 / N_{i} * \Sigma\left(X_{i i}-X_{i}\right)^{2}$

or: $\operatorname{Var} X=W+B$ ( where $W=$ within group inequality and $B=$ between group inequality)

with, $W=\Sigma N_{i} / N * \operatorname{Var}\left(X_{j}\right)$ and $B=\Sigma N_{i} / N^{*}\left(X_{i}-X\right)^{2}$

$X_{i}$ is the average income of the $j$ th population group. The term $\operatorname{Var}\left(X_{j}\right)$ reflects the degree of inequality within the jth population group.

Adjusting the formula for our present case with two group i.e., Rich and Poor households as the two strata of interest, we get;

$\operatorname{Var}(X)=N_{p} / N * \operatorname{Var}\left(X_{p}\right)+N_{r} / N * \operatorname{Var}\left(X_{r}\right)+N_{f} / N\left(X_{p}-X\right)^{2}+N_{s} / N\left(X_{s}-X\right)^{2}$

Where, $\operatorname{Var}(X)=$ total income variances (i.e., total income inequality).

$N_{\mathrm{r}} / \mathrm{N}, \mathrm{N}_{\mathrm{r}} / \mathrm{N}=$ the relative size of poor $(\mathrm{p})$ and rich $(\mathrm{r})$ households within the population (value ranges from 0 to 1$)$.

$\operatorname{Var}\left(X_{p}\right), \operatorname{Var}\left(X_{r}\right)=$ the income inequalities within the respective strata.

$X_{p}, X_{r}=$ average income for the poor and the rich households.

$X=$ average income for the total population.

Note: The formula is used in two different situations namely: with and without income from private trees and the resulting inequalities are compared. The research due to its nature requires lengthy formulas and tedious calculations however we have avoided details.

\footnotetext{
${ }^{3}$ Most of those studies are based on average without any analysis for statistical significance or other empirical evidences.

${ }^{-1}$ An income source that has an equalising effect on its distribution is socially justifiable.

${ }^{5}$ An Indo-Aryan ethric group widely distributed in Nepal.

"A Tibeto-Burmese group with nearly 10,000 population in Nepal.

${ }^{7}$ Three different colors represent poorest, average and richest households however for the sake of convenience only no wealth classes are considered for detail analysis.

${ }^{8}$ The article is published in a local journal however it is also available at: http://www.geocities.cc:n/RainForest/Wetlands/1808/ journal/journal99.htm

"Heerink, N., 1997. Lecture notes on income distribution of Macroesonomic poligy and analysis d100-209, Department of Development, Wageningen Agricultural University, The Netherlands. (also handout)
} 
land-type, income from private trees and household income. Statistical tools mainly Chi-square test was applied to determine the significance of difference. The impact on income distribution was measured in terms of within (i.e. within poor and rich households) and between (i.e. between poor and rich households) group inequalities and the total income inequalities were computed by using the income variance method (Heerink 1997; Sharma 2000).

\section{Finding and discussion}

In this paper, we have not analysed the relationship between intensity of cropping and size of landholding. However it is observed that the intensity of cropping is strongly related with the type of land in possession itself. For example, $K$ het is intensively used for cropping than the Pakbabari and it subsequently reduces the scope for tree growing. Moreover, retention or plantation of trees in Khet, may have other dimensions e.g. cultural and religion. The findings of this paper refute earlier statistics on private tree-holdings while a few are plausible outcomes. Non-parametric test for statistical significance shows that tree-holding by wealth class is not significant.

\section{Land resource}

Agriculture is the main stay of village economy in the hills of Nepal. However, there is meagre land resource. The land resource owned by the sampled 42 households is less than 12 hectares in total. Hence the average landholding is 0.3 hectare per household in the study area. The richest $1 / 3^{\text {rd }}$ households own $63 \%$ and $51 \%$ of $K$ het and Pakhabari respectively. The remaining $2 / 3^{\text {rd }}$ of households, comprising of average and poorest, own about 37 and 49 percents of Khet and Pakhabari respectively (Table-1).

Table 1: Ownership of irrigated or rain-fed rice field and upland by wealth class

\begin{tabular}{lcc}
\hline & \multicolumn{2}{c}{$\%$ of land } \\
\cline { 2 - 3 } Wealth class & Khet & Pakbabari \\
\hline $1 / 3^{\text {nt }}$ poorest & 13.3 & 13.1 \\
$1 / 3^{\text {nt }}$ average & 24.0 & 35.7 \\
$1 / 3^{\text {nt }}$ richest & 62.7 & 51.2 \\
\hline Total area (hectares) & 3.75 & $-\frac{1}{8} .00$ \\
\hline
\end{tabular}

The inequality in land distribution is pronounced especially in case of Khet. Nevertheless, Pakbabari is an important resource that is possessed by all except a few landless households ${ }^{10}$. The ownership of Khet distinguishes the rich and the poor households, and is one of the culturally appropriate indicators of wealth. It is a prestige in Nepal to own Khet among the farming communities and the disparity is more evident by it's ownership. The statistical analysis of this disparity in land ownership is presented in table-2.

More than half of the poor households didn't own Khet where paddy is cultivated, while $85 \%$ of the rich households owned it. The Chi-square test shows significant difference between the rich and poor households regarding the ownership of Khet. There is no significant difference between the rich and the poor households regarding the ownership of Pakhabari. Nonetheless, there is significant difference regarding the magnitude of holding (see Table-2).

Table 2: Land ownership by wealth class (Pearson's chi-square value within the parenthesis)

\begin{tabular}{lll}
\hline & \multicolumn{2}{c}{ \% of bousebolds } \\
\cline { 2 - 3 } Land ype & Rich & Poor \\
\hline Khet & & \\
No & 7.1 & 26.2 \\
Yes & 42.9 & 23.8
\end{tabular}

Pakbabari

No

$(6.9)^{* *}$

Yes

If yes:

$\begin{array}{lll}<0.2 \text { hectare } \quad 23.8 & 45.2\end{array}$

$>0.2$ hectare $\quad 26.2$

$(9.0)^{* *}$

$\overline{\text { Significance levels } *<.05 * *<.01 * * *<.001 \text { a: } 2 \text { cells have }}$ expected count less than 5 so Fisher's exact test (2-sided significance) $=0.232$

If a comparison is made between land possession and proportionate differences in income, with less proportionate difference in income than that of the land ownership, one may assume that the land in possession of the poor is more intensively used than those in rich's possession. However, table-2, regarding the ownership of Khet, suggests significant difference between the poor and the rich households. As the Khet is intensively used than the Pakbabari for cropping, the above logic, regarding the difference in intensity of land use by wealth class, is not valid.

\footnotetext{
"According to Subedi et al. (1990) landless comprise only $10 \%$ of the poor in a study carried out in the Eastern Terai region of
Nepal.
} 
The rich household owns more trees (three times on average) than the poor household (Table-4) however there is no empirical evidence (not significant in Chisquare test) to suggest that there are more trees in land owned by the rich class, implying lower intensity of cultivation. There is no difference between rich and poor houscholds in number of trees in Pakhabari (table-5). Hence, there is no negative impact of tree growing on the income of the poor households.

\section{Trees in private land}

Private trees, in farmland, are one of the significant complementary resources as forest is highly integrated with the farming system in the hilly areas of Nepal. Trees are mostly raised in the Pakbabari and only a few of them like Handebayer (Zizyphus incurva), Bains (Salix spp.) are found in the Khet. Others like Utis (Alnus nepalensis) and Lapsi (Cboerspondias axillaris) are abundant in the Pakbabari. Bamboo is also prominent as it has high demand among the local people. The size of landholding is not related with tree density but the average number of tree per farmer increases with landholding size (Withington et al. 1988)

There are no preferential differences in trees planted between the rich and the poor households. The trees that are planted or retained in the farmland depend on type of land owned. Khet is mostly devoid of trees except for those mentioned. Among many species of trees in Pakbabari, Choerospondias axillaries is the most important, as it directly contributes in cash.

The local people prefer to keep at least a few fruit trees in their courtyard. Those fruit trees in the courtyard are important source of vitamin and nutrients. Cboerospondias axillaris is regarded as a multipurpose tree as besides fruit, it is also an important source of timber and fuelwood. A list of some of the most important trees, common in the research area, and their uses is given in the table 3 .

The trees on private lands belong to the owner, except for a few species enlisted in the Nepal Gazette, the owner has full right to dispose the trees as per his or her wish. As reported elsewhere in literature, the rich households own more private trees than that of the poor households both on absolute terms and on average. However the range of holding and subsequently the standard deviation of the distribution is also higher than that for the poor household. The basic statistics related with private trees by wealth class is given in table- 4 .

Table 4: Basic statistics of private trees owned by rich and poor households in the research area in private land

\begin{tabular}{lcc}
\hline & \multicolumn{2}{c}{ Households } \\
& Poor $(\mathrm{N}=21)$ & Rich $(\mathrm{N}=21)$ \\
\hline Total number & 164 & 583 \\
Per household average & 7.8 & 27.8 \\
Range (Maximum-minimum) & $26-0$ & $120-0$ \\
Standard deviation & 7.53 & 32.65 \\
\hline
\end{tabular}

Retention or growing of trees in Kbet or Pakbabari is not significant by wealth class. It may have other dimensions e.g. culture and religion etc. hence, beyond the scope of paper. The finding related with private trees under different types of land by wealth class is presented in table- 5 .

Table 3: Common private trees in Badikhel, Lalitpur and their uses

\begin{tabular}{|l|l|l|}
\hline \multicolumn{1}{|c|}{ Local name } & \multicolumn{1}{|c|}{ Latin name } & \multicolumn{1}{c|}{ Uses } \\
\hline Alubokhra & Prunus domestica & edible fruit \\
Aru & Prunus persica & edible fruit \\
Bains & Salix spp & firewood \\
Bogate & Maesa macropbylla & edible fruit \\
Haluwabed & Diospyros virginiana & edible fruit \\
Handebayer & Ziopphus incurva & firewood \\
Jyamir & Citrus spp & edible fruit \\
Lapsi & Cboerospondias axillaris & edible fruit, timber, firewood \\
Naspati & Pyrus comminis & edible fruit \\
Suntola & Citrus reticulata & edible fruit, firewood \\
Utis & Almus nepalensis & firewood, domestic use, timber \\
\hline
\end{tabular}


Table 5: Ownership of private trees by wealth class under different land-types (Pearson's chi-square value within the parenthesis).

\begin{tabular}{|c|c|c|}
\hline & \multicolumn{2}{|c|}{$\%$ of bousebolds } \\
\hline & Rich & Poor \\
\hline Kbet & & \\
\hline No & 38.1 & 11.9 \\
\hline Yes & 4.8 & 11.9 \\
\hline Missing ${ }^{1}$ & \multicolumn{2}{|c|}{$\left(5.19^{2}\right)$} \\
\hline Pakhabari & & \\
\hline$<10$ trees & 21.4 & 28.6 \\
\hline$>10$ trees & 28.6 & 19.0 \\
\hline Missing $^{2}$ & $(1.53)$ & 2.4 \\
\hline
\end{tabular}

1 the households that do not own Khet are missing: rich=3, poor $=11$

2. Only one landless household is missing. Actually, three households do not own Bari, however two of them own Pakhabari where trees are grown

a: validation rule requires Fisher's exact test: 2 -sided significance $=0.063$

\section{Contributions to household income}

Income from private trees constitutes 4.8 percent of the monthly income of the $1 / 3^{\text {rd }}$ poorest households. The income is not necessarily in terms of cash but also in terms of subsistence use. The share of private trees in monthly income is highest in case of the average $1 / 3^{\text {rd }}$ households constituting 5.8 percent of it. The income from private trees, in absolute terms, is highest for the richest $1 / 3^{\text {rd }}$ households. However, it constitutes only 3.8 percent of their income. Average monthly household income and contributions from private trees is presented in table-6. In table-7 average monthly income between the poor and the rich households is compared. The average monthly income from private trees for poor and rich group is NRs 117 and NRs 296 respectively" (NRs $75=$ US $\$ 1$ ).

Table 6: Average monthly household income and contribution from private trees in Nepalese currency (NRs)

\begin{tabular}{lcc}
\hline Households & \multicolumn{2}{c}{ Montbly income } \\
& Private trees & Total \\
\hline $1 / 3^{\text {rd }}$ poorest & 157 & 3277 \\
$1 / 3^{\text {} t}$ average & 235 & 4049 \\
$13^{\text {nt }}$ richest & 267 & 7058 \\
\hline
\end{tabular}

Impact on income distribution

Private trees give an opportunity for diversifying source of houschold-income besides providing important source of nutrients for poor women and children. The decomposition analysis of income variances under hypothetical situations: viz, with and without income from private trees, is given in table7. The calculation of variances shows that both 'within group inequality' and 'between group inequality' increases due to the income from private trees. Hence, increased income from private trees fails to reduce total inequality, diminishing any prospect of increased income from private trees leading to a reduction in inequality. The finding of this research shows "income from private trees has a dis-cqualising effect on income distribution".

Table-7: Decomposition analysis of monthly household income with and without private trees

\begin{tabular}{lcc}
\hline & \multicolumn{2}{c}{ Monthly income in NRs } \\
\cline { 2 - 3 } Particulars & With private trees & Without private trees \\
\hline Average monthly income & & \\
$\quad$ Poor & 3401 & 3284 \\
$\quad$ Rich & 6785 & 6489 \\
Weighted average income & 5329 & 5111 \\
Standard deviation & & \\
$\quad$ Poor & 1308 & 1311 \\
$\quad$ Rich & 2943 & 2869 \\
Income inequality $\left({ }^{*} 10^{*}\right)$ & & \\
$\quad$ Within group & 0.567 & 0.543 \\
$\quad$ Between group & 0.281 & 0.252 \\
Total inequality & 0.848 & 0.795 \\
\hline
\end{tabular}

\section{Conclusion and Recommendation}

Based on the analysis of findings, the following are the main conclusions:

- Pakbabari is an important land asset of poor households.

- There is no significant difference between poor and rich household regarding tree-holding in private land.

- Income of private tree has dis-equalising effect on income distribution.

The above conclusions drawn from the present research should have a sobering effect on those concerned with issues of equity in Community Forestry of Nepal. As most of the concerns arising due to equality in product distribution from the community forests is unfounded.

\footnotetext{
"These figures are obtained by deducting the average monthly income under private trees situation with similar income under without private trees situation in table-7 for respective wealth classes.
} 
Income accrued from the private trees do not reduce 'poor-rich' gap. As this is a case study, one should refrain from generalising the finding and any hasty conclusion can be erroneous and premature. However, we recommend that questions regarding private endowment of resources, private trees in particular, be explored further before criticising the practices within Community Forestry in the name of equity.

Further research is needed in private resource endowment before criticising the practices (equality based) of distributing forest products from the community forests in the name of failing to ensure equity in Nepal.

\section{Acknowledgement}

The authors thank anonymous peer-reviewers for their suggestions and comments. This paper was presented in XII World Forestry Congress, Qubec, Canada from September 19-28, 2003.

\section{References}

Filius, A. M. and A. R. Sharma, 1999. Socioeconomic stratification by wealth ranking - a valid approach. The Nepal Journal of Forestry, Nepal Foresters' Association, Kathmandu, Nepal. 11(1):1-12. (URL:http://www.geocities.com/RainForest/ Wetlands/1808/journal/journal99.htm)
Heerink, N., 1997. Lecture notes on income distribution of Macroeconomic policy and analysis d100-209, Department of Development, Wageningen Agricultural University, The Netherlands. (also handout).

Malla, Y.B., 1993. Changing role of the forest resource market: an ignored dimension of Community Forestry. Banko Janakari, Forest Research Division, Nepal. 4(1).

Malla, Y.B., H.R. Neupane and P. Branney, 2000. Sharing and reflection of quantitative information with community forest users. Forest User Groups Forest Management Project (DFID R6918), Discussion Paper No. 5. Reading, UK, University of Reading.

Sharma, A. R., 2000. Glamour and gripes of community forestry: impact on income distribution. Banko Janakari, Department of Forest Research and Survey, Kathmandu, Nepal. 10 (2): 9-14.

(URL: http://www.biodiv-nepal.gov.np/ banko102.html)

Subedi, B.P., C.M.L Das and D.A. Messerschmidt, 1990. Indigenous knowledge of tree and forest resources in the Eastern Nepal Terai.

Withington, D., K. G. MacDicken and C.B. Sastry [eds.], 1988. Winrock Intenational, F/FRED. Pattaya, Thailand. 1-5 November. 